\title{
Kajian Karakteristik Fisikokimiawi, Mikrostruktur dan Nilai Ekonomis Synbiotic Fermented Milk Guna Menunjang Pola Hidup Sehat
}

\section{(Study of Physicochemical Charateristics, Microstructures and Economic Values of Synbiotic Fermented Milk to Support A Healthy Lifestyle)}

\author{
Sawitri ME, Wisaptiningsih U, Indrati R \\ Fakultas Peternakan, Universitas Brawijaya \\ maniksawitri@gmail.com
}

\begin{abstract}
Functional food products enriched with probiotics and prebiotics such as synbiotic fermented milk have a dietary function, contain bioactive peptide components, prevent disease and support a healthy lifestyle. This study aims to examined the physical (viscosity and syneresis) and chemical (lactic acid, fat, protein contents) characteristics, microstructures (CLSM) and economic values of the synbiotic fermented milk. The materials used included skimmed milk powder, inulin, standard yoghurt culture starter (Lactobacillus bulgaricus FNCC-0041 and Streptococcus thermophilus FNCC-0040 from the Center of Food and Nutrition Study, Universitas Gajah Mada University) with a ratio of 1:1 (v/v). The study employed an experimental method with Complete Randomized Design, without inulin fortification $\left(\mathrm{K}_{0}\right)$ and with $2 \%$ inulin fortification $\left(\mathrm{K}_{1}\right)$. The results indicate that at the isoelectric point, $K_{1}$ highly significant increases the viscosity and protein content $(P<0.01)$ and significantly reduces syneresis $(\mathrm{P}<0.05)$ and the fat content. The microstructure analysis showed that $2 \%$ inulin fortification at $\mathrm{pH} 4.5$ is able to strengthen the gel formation with finerand more uniform structures. By the end of the fermentation process, $1000 \mathrm{ml}$ skim milk results in $1100 \mathrm{ml}$ synbiotic fermented milk, packaged @ $120 \mathrm{ml} / \mathrm{cup}$. The calculation of economic value shows that profits of $36375 \mathrm{IDR} /$ liter $\left(\mathrm{K}_{1}\right)$ and $34,375 \mathrm{IDR} / \mathrm{liter}\left(\mathrm{K}_{0}\right)$. It can be concluded that $2 \%$ inulin can function as a dietary fiber, stabilizer, thickening agent and texture modifier of a synbiotic fermented milk and provide benefits based on the economic analysis.
\end{abstract}

Key words: Inulin, physicochemical, microstructure, synbiotic fermented milk

\begin{abstract}
ABSTRAK
Produk pangan fungsional yang diperkaya dengan probiotik dan prebiotik seperti synbiotic fermented milk memiliki fungsi diet, mengandung komponen peptida bioaktif, mencegah terjadinya penyakit serta menunjang pola hidup sehat. Penelitian ini bertujuan untuk mengkaji karakteristik fisik (viskositas, sineresis), kimiawi (asam laktat, kadar lemak, kadar protein), mikrostruktur (CLSM) dan nilai ekonomis synbiotik fermented milk. Materi penelitian adalah susu skim bubuk, inulin (CV. Gamma Scientific Biolab), kultur starter yoghurt standard (Lactobacillus bulgaricus FNCC-0041 dan Streptococcus thermophilus FNCC-0040 dari Pusat Studi Pangan dan Gizi, Universitas Gajah Mada) dengan rasio 1:1 $(\mathrm{v} / \mathrm{v})$. Metode percobaan dengan Rancangan Acak Lengkap, tanpa fortifikasi inulin $\left(\mathrm{K}_{0}\right)$ dan dengan fortifikasi inulin $2 \%\left(\mathrm{~K}_{1}\right)$. Pada titik isoelektris, $\mathrm{K}_{1}$ meningkatkan viskositas dan kadar protein secara sangat nyata $(\mathrm{P}<0,01)$ serta secara sangat nyata menurunkan sineresis $(\mathrm{P}<0,01)$ dan kadar lemak. Mikrostruktur menunjukkan bahwa fortifikasi inulin $2 \%$ pada $\mathrm{pH} 4,5$
\end{abstract}


memperkuat pembentukan gel dengan struktur yang lebih halus, kompak dan seragam. Pada akhir fermentasi dari $1000 \mathrm{ml}$ susu skim dihasilkan $1100 \mathrm{ml}$ synbiotic fermented milk, dikemas @120 ml/cup dan dari perhitungan nilai ekonomisnya diperoleh keuntungan $\mathrm{K}_{1}$ sebesar Rp 36.375,-, $\mathrm{K}_{0}$ sebesar Rp 34.375,-/liter. Disimpulkan bahwa inulin 2\% dapat berfungsi sebagai dietary fiber, stabilizer, thickening agent dan textur modifier synbiotic fermented milk serta memberikan keuntungan ditinjau dari analisis ekonomisnya.

Kata kunci: Inulin, fisikokimiawi, mikrostruktur, synbiotic fermented milk

\section{PENDAHULUAN}

Permintaan produk pangan fungsional yang diperkaya dengan probiotik seperti yoghurt akhir-akhir ini mengalami peningkatan, pangan tidak dimaksudkan hanya untuk memuaskan rasa lapar saja tetapi harus dapat menyediakan nutrisi yang diperlukan untuk pencegahan penyakit, peningkatan harapan hidup dan peningkatan kualitas hidup masyarakat modern, meskipun hingga saat ini konsumsi yoghurt masih didominasi oleh kalangan menengah ke atas. Kini terjadi kecenderungan bahwa produk yoghurt probiotik yang diketahui berfungsi sebagai pangan fungsional, dalam pengolahannya dilakukan fortifikasi dengan prebiotik kedalam formulasinya menjadi synbiotic fermented milk, dengan tujuan untuk meningkatkan kualitas yoghurt, meningkatkan aktivitas dan daya hidup probiotik serta meningkatkan efek therapeutic bagi kesehatan (Grajek et al. 2005, Aswal et al. 2012). Selama ini produk olahan pangan yang diperkaya dengan serat seperti inulin ditujukan untuk diet karena kesadaran akan kesehatan, tetapi konsumen tetap menuntut pangan dengan penerimaan dan cita rasa yang enak, berserat tinggi, rendah lemak dan kalori (Venter 2007).

Komposisi fermented milk secara umum adalah kadar protein 4-6\%, keasaman tertitrasi 0,6-1,3\%, kadar lemak 0,1-1\%, laktosa 2-3\%, pH 3,8-4,6 dan jumlah bakteri asam laktat minimal $10^{7}$ (cfu/g) (Susilorini \& Sawitri 2011). Nilai nutrisi yang di kandung antara lain karbohidrat $4,7 \mathrm{~g}$, lemak $3,3 \mathrm{~g}$, protein $3,5 \mathrm{~g}$, serta trace element vitamin A, vitamin B2 (riboflavin) dan energi $257 \mathrm{KJ}$, tergantung bahan baku dan proses pengolahannya. Sawitri (2018) meneliti bahwa produk yoghurt sinbiotik rendah lemak yang diperkaya dengan prebiotik inulin $2 \%$ mengandung rataan kadar lemak $0,06 \%$, kadar protein $4,15 \%$, kadar asam laktat $0,26 \%$, total bakteri asam laktat 9,21 log cfu/ml. Sumber inulin banyak dijumpai pada keluarga compositae dan graminae, disimpan sebagai cadangan karbohidrat, seperti pada umbi bunga dahlia (Dahlia pinnata), chicory (Chichorium intyhus), jerusalem artichoke (Helianthus tuherisus L). Tumbuhan di Indonesia yang cukup mengadung inulin ditemui pada pisang, bengkoang, asparagus, tomat, daun bawang serta bawang putih (Simanjuntak et al. 2004).

Inulin secara alamiah mengandung fruktooligosakarida, memiliki sifat sebagai serat pangan (dietary fiber) yang larut dalam air sehingga bermanfaat bagi proses metabolisme (Akin et al. 2007). Inulin bertindak sebagai stabilizer yang dapat mengikat air, menstabilkan sistem koloid susu yakni berinteraksi di permukaan misel kasein sehingga jaringan kasein menjadi kuat dan dapat mencegah sineresis (Hematyar et al. 2012), berperan sebagai texture modifier yang dapat mempengaruhi viskositas, mikrostruktur dan kualitas organoleptik yoghurt (Guggisberg et al. 2009). Inulin tidak berwarna, tidak berbau, tidak berasa (hambar), berupa bubuk putih yang mudah dikombinasikan dengan bahan lain tanpa mengubah flavour (Saeed et al. 2015) disamping sebagai pemanis rendah kalori, dapat meningkatkan thickness pada produk (Glibowski et al. 2011).

Manfaat synbiotic fermented milk bagi kesehatan antara lain proteksi terhadap gangguan pencernaan, menurunkan kolesterol, meningkatkan pencernaan laktosa bagi 
penderita lactose intolerance, meningkatkan respon imun, mencegah terjadinya kanker khususnya kanker colon, penerimaan yang lebih baik terhadap protein, besi dan kalsium karena adanya bakteri yang hidup dalam yoghurt disamping karena seratnya (Aghjani et al. 2014). Sawitri et al. (2008) menyatakan bahwa probiotik pada yoghurt dapat mencegah peningkatan kolesterol di dalam darah dengan jalan mengasimilasi kolesterol kemudian menyimpannya di dalam tubuh sehingga kolesterol tidak dapat terserap oleh serum darah.

Setelah proses fermentasi pada synbiotik fermented milk, $80 \%$ protein susu yang berupa kasein akan menghasilkan metabolit berupa bioaktif peptida akibat hidrolisis enzimatis yang dihasilkan oleh bakteri asam laktat, juga conjugated linoleic acid, sphingolipid dan butirat serta dapat berfungsi sebagai antioksidan, antimikroba dan imuno-modulator (Grajek et al. 2005). Penambahan inulin 2\% menghasilkan sinbiotik yang tepat dan ekonomis (Franck \& de Leenheer 2005), mendorong perkembangan dan kelangsungan hidup total bakteri asam laktat selama fermentasi (Akin et al. 2007). Tercapainya titik isoelektris akan terjadi interaksi kasein-kasein yang maksimal, sehingga kasein menyatu dan terjadi pengkerutan protein pada fermented milk, sedangkan penambahan stabilizer akan menghasilkan mikrostruktur yang lebih seragam, halus dan kompak (Sawitri et al. 2018).

Berdasarkan uraian di atas dilakukan penelitian yang mengkaji karakteristik synbiotic fermented milk yang diperkaya dengan inulin diharapkan dapat mencegah pemisahan fase, meningkatkan viskositas dan memperbaiki tekstur. Synbiotik fermented milk dapat digunakan sebagai pangan fungsional asal susu, mengandung probiotik, kaya serat yang bermanfaat untuk menunjang pola hidup sehat.

\section{MATERI DAN METODE}

Materi penelitian susu skim bubuk, inulin (CV. Gamma Scientific Biolab), kultur starter yoghurt standard (Lactobacillus bulgaricus FNCC-0041 dan Streptococcus thermophilus FNCC-0040 dari Pusat Studi Pangan dan Gizi, Universitas Gajah Mada) dengan rasio 1:1 (v/v). Metoda percobaan dengan Rancangan Acak Lengkap 2 perlakuan yaitu, tanpa fortifikasi inulin $\left(\mathrm{K}_{0}\right)$ dan fortifikasi inulin $2 \%\left(\mathrm{~K}_{1}\right)$ dengan 3 ulangan. Karakteristik fisik meliputi viskositas (viskometer rotasional merk Elcometer 2300), sineresis (metode sentrifugasi yang telah dimodifikasi), kimiawi (kadar asam laktat, kadar lemak dan kadar protein menurut AOAC 2000), mikrostruktur (Confocal Laser Scanning Microscopy/CLSM menurut Supavititpatana et al. 2009). Data karakteristik synbiotic fermented milk dianalisis menggunakan ANOVA, gambar hasil pengamatan mikrostruktur dianalisis kuantitatif dengan membandingkan struktur yang terbentuk.

\section{HASIL DAN PEMBAHASAN}

\section{Karakteristik fisik synbiotic fermented milk}

Rataan viskositas dan sineresis synbiotic fermented milk disajikan pada Tabel 1. 
Tabel 1. Rataan karakteristik fisik synbiotic fermented milk

\begin{tabular}{lcc}
\hline \hline Perlakuan & Viskositas $(\mathrm{cP})$ & Sineresis \\
\hline $\mathrm{K}_{0}$ & $765,56^{\mathrm{a}}$ & $0,023^{\mathrm{a}}$ \\
$\mathrm{K}_{1}$ & $967,33^{\mathrm{b}}$ & $0,014^{\mathrm{b}}$ \\
\hline
\end{tabular}

$\mathrm{K}_{0} \quad$ : Tanpa fortifikasi inulin

$\mathrm{K}_{1} \quad$ : Fortifikasi inulin $2 \%$

ab : Superskrip ab pada kolom yang sama berbeda sangat nyata pada masing-masing perlakuan $(\mathrm{P}<0,01)$

Rataan viskositas $\mathrm{K}_{1}$ menunjukkan berbeda sangat nyata $(\mathrm{P}<0,01)$ lebih kental daripada rataan viskositas $\mathrm{K}_{0}$. Penggunaan susu skim sebagai bahan baku mempengaruhi kekentalan (Franck \& de Leenheer 2005). Pada post acidification, fortifikasi inulin 2\% memberikan nilai viskositas tertinggi sejalan dengan penurunan $\mathrm{pH}$ (Sawitri 2018). Inulin bertindak sebagai thickener, mempunyai sifat menahan air dan akan membentuk kompleks melalui jembatan hidrogen dengan protein dan berkontribusi terjadinya peningkatan viskositas (Rinaldoni et al. 2012). El-Nagar et al. (2002) menyatakan adanya interaksi dietary fiber dengan komponen liquid pada susu meningkatkan viskositas.

Rataan sineresis $\mathrm{K}_{1}$ menunjukkan berbeda sangat nyata $(\mathrm{P}<0,01)$ terhadap rataan sineresis $\mathrm{K}_{0}$. Penambahan stabilizer yang berinteraksi dengan kasein akan menurunkan sineresis (Hematyar et al. 2012). Penggunaan beberapa bahan tabahan seperti pektin, gelatin dan prebiotik dapat menurunkan persentase sineresis (Aghjani et al. 2014). Yoghurt plain bebas lemak yang ditambahkan inulin dapat menurunkan terjadinya sineresis (Sawitri et al. 2018). Sineresis dipengaruhi oleh keasaman, pH dan daya ikat air, tanpa partisipasi gelatin dalam formasi jaringan globula lemak, sineresis semakin meningkat dan kualitas yogurt semakin tidak memuaskan (Sawitri et al. 2008).

\section{Karakteristik kimiawi synbiotic fermented milk}

Rataan asam laktat, kadar lemak dan kadar protein synbiotic fermented milk seperti disajikan pada Tabel 2.

Tabel 2. Rataan karakteristik kimiawi synbiotic fermented milk

\begin{tabular}{lccc}
\hline \hline Perlakuan & Asam laktat $(\%)$ & Kadar lemak $(\%)$ & Kadar protein $(\%)$ \\
\hline $\mathrm{K}_{0}$ & 0,13 & 0,067 & $3,65^{\mathrm{a}}$ \\
$\mathrm{K}_{1}$ & 0,26 & 0,059 & $4,15^{\mathrm{b}}$ \\
\hline
\end{tabular}

$\mathrm{K}_{0}$ : Tanpa penambahan inulin $2 \%$

$\mathrm{K}_{1}$ : Dengan penambahan inulin $2 \%$

ab : Superskrip ab pada kolom yang sama berbeda sangat nyata pada masing-masing

perlakuan $(\mathrm{P}<0,01)$

Fortifikasi inulin $\mathrm{K}_{1}$ memberikan rataan kadar asam laktat yang lebih tinggi daripada $\mathrm{K}_{0}$, meskipun secara statistik tidak berbeda nyata $(\mathrm{P}>0,05)$. Yoghurt dengan bakteri asam laktat sebagai starter dengan penambahan inulin akan memanfaatkan laktosa dalam susu skim dihidrolisis oleh enzim dehidrogenase menjadi asam laktat (Aryana et al. 2007). Inulin merangsang pertumbuhan dan aktivitas starter dan menghasilkan asam laktat yang sangat luar biasa (Aghjani et al. 2014). 
Fortifikasi inulin $\mathrm{K}_{1}$ memberikan rataan kadar lemak yang lebih rendah daripada $\mathrm{K}_{0}$, meskipun secara statistik tidak berbeda nyata $(\mathrm{P}>0,05)$. Inulin sebagai prebiotik akan difermentasikan oleh probiotik menghasilkan asam lemak rantai pendek dalam bentuk asam asetat, asam butirat dan asam propionat yang termasuk Short Chain Fatty Acid (SCFA) (Grajek et al. 2005).

Fortifikasi inulin $\mathrm{K}_{1}$ memberikan rataan kadar protein yang lebih tinggi daripada $\mathrm{K}_{0}$, berbeda sangat nyata $(\mathrm{P}<0,01)$. Penggunaan bahan baku susu skim meningkatkan protein, serta memacu pertumbuhan bakteri asam laktat (Desnilasari \& Lestari 2014). Sawitri (2018) menyatakan kenaikan kadar protein selain karena susu skim sebagai bahan baku yoghurt sinbiotik, juga sebagian besar bakteri probiotik dibangun dari protein.

\section{Mikrostruktur synbiotic fermented milk}

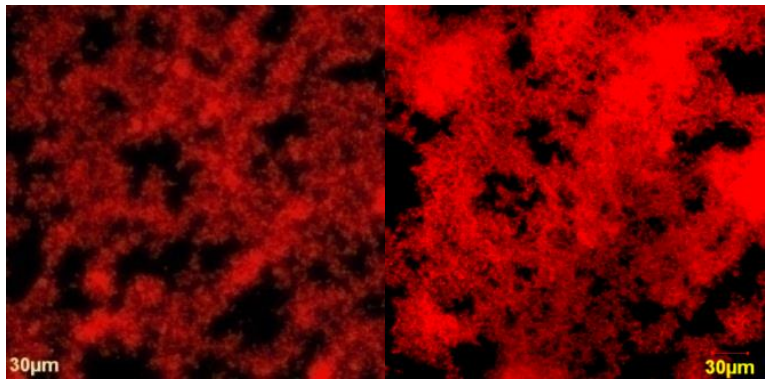

Gambar 1. Mikrostruktur fermented milk

Perlakuan $\mathrm{K}_{1}$ menunjukkan bahwa fortifikasi inulin $2 \%$ memperkuat jaringan gel membentuk gelasi karena adanya interaksi kasein-inulin-kasein yang lebih seragam, halus dan kompak serta terbentuknya produksi eksopolisakarida dibandingkan dengan $\mathrm{K}_{0}$ yang mengalami flok-flok agregasi dengan ukuran yang tidak seragam. Struktur synbiotic fermented milk secara keseluruhan dapat menghambat sineresis dan permiabilitas yang berlebih serta penyumbatan bagian-bagian yang membentuk pori-pori. Interaksi yang mungkin terjadi antara protein kasein dengan inulin yaitu adanya ikatan hidrogen dan interaksi hidrofobik (Povolny \& Smith 2002).

\section{Nilai ekonomis synbiotic fermented milk}

Perhitungan nilai ekonomis synbiotic fermented milk disajikan pada Tabel 3. Bahan baku 1 liter susu skim setelah difermentasi menjadi fermented milk plain sebanyak 1100 $\mathrm{ml}(10 \%$ dari $1000 \mathrm{ml}$ karena hasil fermentasi yaitu asam laktat, bioaktif peptida, eksopolisakarida dan asam2 lainnya). Dikemas dalam cup berisi @120ml sehingga dihasilkan 9 cup dan dipasarkan dengan harga Rp. 10.000,- $\left(\mathrm{K}_{0}\right)$ dan $\mathrm{Rp} 12.000$,- $\left(\mathrm{K}_{1}\right)$. Keuntungan yang diperoleh $\mathrm{K}_{0}$ sebesar $\mathrm{Rp} 34.375$,- dan $\mathrm{K}_{1}$ sebesar $\mathrm{Rp} 36.375$,-. Synbiotic fermented milk dengan fortifikasi inulin $2 \%$ memberikan keuntungan yang lebih besar daripada fermented milk ditinjau dari nilai ekonomisnya, dimana serat sebagai dietary fiber menyehatkan dan menguntungkan dalam menunjang pola hidup sehat. 
Tabel 3. Biaya produksi $\mathrm{K}_{0}$ dan $\mathrm{K}_{1}$ per liter

\begin{tabular}{lrr}
\hline \hline Macam & $\mathrm{K}_{0}(\mathrm{Harga} / \mathrm{Rp})$ & $\mathrm{K}_{1}(\mathrm{Harga} / \mathrm{Rp})$ \\
\hline Biaya tidak tetap & & \\
Susu skim $(100 \mathrm{~g})$ & 8.000 & 8.000 \\
Starter yoghurt $(30 \mathrm{ml})$ & 10.500 & 10.500 \\
Aquadest $(1000 \mathrm{ml})$ & 1.000 & 1.000 \\
Inulin (20g) & - & 16.000 \\
Gas LPG & 1.500 & 1.500 \\
Botol pemeram & 15.000 & 15.000 \\
Aluminium foil & 1.000 & 1.000 \\
Kemasan (9 bj)/@ 120ml & 18.000 & 18.000 \\
\hline Total biaya tidak tetap & 55.000 & 71.000 \\
\hline Biaya tetap & & 280 \\
Penyusutan pemanas & 280 & 280 \\
Penyusutan timbangan & 280 & 55 \\
Penyusutan gelas takar & 55 & 10 \\
\hline Penyusutan pengaduk & 10 & 625 \\
\hline Total biaya tetap & 625 & 71.625 \\
\hline Total biaya produksi & 55.625 & 108.000 \\
\hline Total biaya penjualan & 90.000 & 36.375 \\
\hline Keuntungan & 34.375 & \\
\hline
\end{tabular}

\section{KESIMPULAN}

Kesimpulan penelitian ini ialah fortifikasi inulin 2\% dapat meningkatkan viskositas, kadar asam laktat, kadar protein dan menurunkan sineresis serta kadar lemak synbiotic fermented milk dengan struktur yang lebih seragam, kompak dan pori-pori yang lebih kecil dan lebih merata. Inulin dapat berfungsi sebagai dietary fiber dalam synbiotic fermented milk yang berguna untuk pola hidup sehat serta ditinjau dari nilai ekonomisnya memberikan keuntungan yang lebih besar.

\section{DAFTAR PUSTAKA}

Aghjani AR, Pourahmad R, Adeli HRM. 2014. The effect of oligofructose, lactulosa and inulin mixture as prebiotic on physicochemical porperties of synbiotic Yogurt. J Food Biosci Technol. 4:33-40.

Akin MB, Akin MS, Kirmaci Z. 2007. Effects of inulin and sugar levels on the viability of yogurt and probiotic bacteria and the physical and sensory characteristics in probiotic ice cream. J Food Chem. 104:93-99.

Aryana KJ, Plauche S, Rao RM, Mc. Grew P, Shah NP. 2007. Fat-free plain yogurt manufactured with inulins of various chain lengths and lactobacillus acidophilus. J Food Sci. 72:79-84. 
Aswal P, Shukla A, Priyadarshi S. 2012. Youghurt: preparation, characteristics and recent advancements. Cibtech J Bio-Protocols. 1:32-33.

Desnilasari D, Lestari NPA. 2014. Formulasi minuman sinbiotik dengan penambahan puree pisang ambon (Musa paradisiacal var sapientum) dan inulin menggunakan inokulum Lactobacillus casei. Agritech. 34:257-265.

El-Nagar G, Clowes G, Tudorica CM, Kuri V, Brennan CS. 2002. Rheological quality and stability of yogurt-ice cream with added inulin. Int J Dairy Technol. 55:89-93.

Franck A, De Leenheer L. 2005. Inulin. Dalam: Steinbuchel A, Rhee SK, editors. Polysaccharides and polyamides in the food industry. Weinheim (Jerman): Wiley-VCH.

Glibowski P, Glibowska A. 2011. The effect of pH, temparature and heating time on inulin chemical stability. Acta Sci Pol Technol Aliment. 10:189-196.

Guggisberg D, Steven JC, Piccinali P, Butikofer U, Eberhard P. 2009. Rheological, microstructural and sensory characterization of low fat and whole milk set yoghurt as influenced by inulin addition. Int Dairy J. 19:107-109.

Grajek W, Olejnik A, Sip A. 2005. Probiotics, prebiotics and antioxidants as functional foods. Acta Biochem Polonia. 52:665-671.

Hematyar N, Samarin AM, Poorazarang H, Elhamirad AH. 2012. Effect of gum on yoghurt characteristics. World Appl Sci J. 20:661-665.

Povolny S, Smith. 2002. Interaction of milk proteins with inulin, protein, carbohydrate interaction. Milchwissenscahft [Internet]. 494-497. Available from: http://www.researchgate.net/publication/279624142

Rinaldoni AN, Campderros ME, Padilla AP. 2012. Physico-chemical and sensory properties of yogurt from ultrafiltreted soy milk concentrate added with inulin. LWT-Food Sci Technol. 45:142-147.

Sawitri ME, Manab A, Palupi TWL. 2008. Kajian penambahan gelatin terhadap keasaman, pH, daya ikat air dan sineresis yogurt. J Ilmu Teknologi Hasil Ternak. 3:35-42.

Susilorini TE, Sawitri ME. 2011. Susu dan produk olahan susu. Jakarta (Indonesia): PT Penebar Swadaya.

Sawitri ME. 2018. Karakteristik yoghurt sinbiotik yang diperkaya dengan inulin [Disertasi]. [Malang (Indonesia)]: Universitas Brawijaya.

Sawitri ME, Rosyidi D, Radiati LE, Purwadi. 2018. The physical quality and microstructure of symbiotic yogurt fortified with inulin at various $\mathrm{pH}$ values. Int J Curr Microbiol App Sci. 7:1052-1058.

Simandjuntak P, Rachmat J, Rosalinda N. 2004. Tumbuhan Indonesia sebagai sumber inulin. J Penelitian Kimia. 3:8-14.

Supavititpatana P, Wirjantoro TI, Raviyan P. 2009. Effect of sodium caseinate and whey protein isolate fortification on the physical properties and microstructure of corn milk yogurt. CMU J Nat Sci. 8:247-263. 